\title{
Growth and Yield Performance of Cassava/Maize Intercrop Under Different Plant Population Density of Maize
}

\author{
O. N. Adeniyan ${ }^{1}$, O. A. Aluko ${ }^{1}$, S. O. Olanipekun ${ }^{1}$, J. O. Olasoji ${ }^{1} \&$ V. O. Aduramigba-Modupe ${ }^{1}$ \\ ${ }^{1}$ Institute of Agricultural Research and Training, Obafemi Awolowo University (OAU), Ibadan, Nigeria \\ Correspondence: O. N. Adeniyan, Institute of Agricultural Research and Training, Obafemi Awolowo \\ University (OAU) P. M. B. 5029 Ibadan, Nigeria. Tel: 234-806-209-9747. E-mail: adeniyantayo@yahoo.com
}

Received: October 8, 2010 Accepted: January 8, 2013 Online Published: July 15, 2014

doi:10.5539/jas.v6n8p35 URL: http://dx.doi.org/10.5539/jas.v6n8p35

\begin{abstract}
Field experiments involving cassava/maize intercrops under different plant population densities of maize were conducted during 2002 and 2003 cropping seasons on the research farm of the Institute of Agricultural Research and Training situated at Ilora, Nigeria $\left(7^{\circ} 22^{\prime \prime}\right.$ N, $3^{\circ} 52^{\prime \prime}$ E). Results obtained in 2002 and 2003 consistently showed that increases in plant population density of maize in maize/cassava intercrop directly increased maize plant height at tasselling, plant height at harvest and plant lodging percentage, but reduced stalk diameter, average cob weight, dry matter yield and grain yield. Significantly least values $(2.03$ and $2.11 \mathrm{t} / \mathrm{ha})$ were obtained from maize grain yield in 2002 and 2003 under 20,000 plants/ha while the highest values (3.28 and 3.55 t/ha) were obtained in 2002 and 2003 under 40,000 plants/ha. Results obtained in 2002 and 2003 showed that increased in plant population density of maize in cassava/maize intercropping system significantly affected the cassava plant height at 2 and 4 month after planting (MAP) and fresh tuber yield. Increased in plant population density of maize in cassava/maize intercrop did not significantly affect cassava plant height at 7 and 12 MAP. The highest values (25.9 and $25.3 \mathrm{t} / \mathrm{ha}$ ) cassava fresh tuber were obtained in 2002 and 2003 under 20,000 plants/ha maize component. The least values (17.6 and $18.2 \mathrm{t} / \mathrm{ha}$ ) were obtained in 2002 and 2003 under 80,000 plants/ha maize component.
\end{abstract}

Keywords: plant height, yield, performance, intercropping, plant population density

\section{Introduction}

The peasant farmers have long recognized the importance of intercropping as a farming practice in the tropics. Intercropping is widely practiced by small-scale farmers as a strategy for increasing crop yields, crop diversity and stability of crop production (Gomez \& Gomez, 1983). Intercropping involves planting together on the same piece of land crops that differ in productivity, growth habit and phonological characteristics (IITA, 1980). It has been noted that intercropping gives higher total returns per unit area of land and this allows larger financial gains for farmers (Baker, 1974).

In humid tropics, maize is traditionally grown in intercrop with cassava (Agboola \& Fayemi, 1971; Fagbamiye, 1977; Ikeorgu et al., 1984). In Nigeria, cassava and maize are the prominent crops in intercropping practices and have been widely studied (Ezumah et al., 1980). Jerome et al. (1988) conducted an explanatory survey in Cameroon and found that maize was mainly intercropped with cassava, while Oyedokun et al. (1989) observed that cassava is planted by most farmers once maize is established or just before maize matures or after it is harvested. Furthermore, according to Cameroon Agricultural Census cited by Jerome et al. (1988) between five major root and tuber crops grown in Cameroon, cassava, cocoyam, yams, sweet potatoes and Solanum potatoes cassava ranks first in total area cultivated. Cassava/maize intercrop has been indicated to be productive and compatible mainly because maize is a short season crop while cassava is a long duration crop (Ikeorgu, 2002). The crops lend themselves to many transformed products and forms (Numfor, 1987). Consequently, cassava and maize production are increasing rapidly.

Adetiloye (1985) commented that the yield advantage of intercropping has not been so marked in several situations possibly due to use of supra optimal plant population proportions for component crops. The effects of crop density on the yield of sole crops are well known (Harper, 1977). However, this information is of little value in predicting the optimum densities of the component crops in intercrops. The yield of each component crop will depend on both inter-specific and intra-specific competitions. The most common reason given for the increased 
yield in intercropping is more efficient use of limiting resources (Vandermeer, 1989). The more efficient use of limiting resources in intercropping can occur because the component crops use the resources either at different times, in different parts of the soil profile or aerial canopy or in different forms. Snaydon and Satorre (1989) defined propensity for plants to interact in these ways as "resource complementarities". Therefore, Troyer and Rosenbrook (1983) having in mind the necessity of higher plant densities for maximum yield per unit land area suggested production under higher plant densities as a means of increasing grain yield of maize. It is necessary to intensify research in testing a wide range of combinations. The objectives of this work therefore, was to determine the effects of different plant population densities of maize on growth and yield performance of maize and component cassava in cassava/maize intercrop.

\section{Materials and Methods}

Field experiment involving cassava/maize intercrop was conducted during the 2002 and 2003 cropping seasons on the research farm of the Institute of Agricultural Research and Training situated at Ilora, Nigeria $\left(7^{\circ} 22^{\prime \prime} \mathrm{N}, 3^{\circ}\right.$ $52^{\prime \prime}$ E). The dominant soil of the experimental area is classified as Egbeda series (Smyth \& Montgomery, 1962).

The experiment was laid out in a completely randomized block design with three replications of four intercropping treatments. The plot size was $4 \mathrm{~m} \times 5 \mathrm{~m}$. Cassava plant population density was maintained at 10,000 plants/hectare, while maize plant density was varied in the intercrops. The treatments were therefore:

i. Cassava/maize intercrop (maize planted at $1 \mathrm{~m} \times 1 \mathrm{~m}$ at 2 plants/stand with plant population density of 20,000 plants/hectare).

ii. Cassava/maize intercrop (maize planted at $1 \mathrm{~m} \times 0.5 \mathrm{~m}$ at 2 plants/stand with plant population density of 40,000 plants/hectare).

iii. Cassava/maize intercrop (maize planted at $1 \mathrm{~m} \times 0.25 \mathrm{~m}$ at 2 plants/stand with plant population density of 80,000 plants/hectare).

iiii. Control cassava/maize intercrop (maize planted at $0.75 \mathrm{~m} \times 0.25 \mathrm{~m}$ at 1 plants/stand with plant population density of 53,333 plants/hectare).

Site was ploughed and harrowed; planting of cassava and maize was done at the same date in first week of May in both year of experimentation. NPK fertilizer 20-10-10 (compound fertilizer) at the rate of $120 \mathrm{~kg} / \mathrm{ha}$ was applied to maize by split-dose application in ring form. The first application was at 3 weeks after planting while the second application was at tasselling. The same brand of fertilizer was applied to cassava at $250 \mathrm{~kg} / \mathrm{ha}$. Plots were weeded as at when due manually throughout the experimentation period.

Data collected on cassava were plant height at 2, 4, 7 and 12 months after planting (MAP) and fresh tuber yield at maturity (12 MAP). Data collected on maize were height at tasselling, plant height at harvest, lodging percentage and grain yield. The results were subjected to statistical analysis of variance and means were compared using Duncan's Multiple Range Test (DMRT) at 0.05 level of probability when F-ratio was significant.

\section{Results and Discussion}

\subsection{Maize}

Results obtained in 2002 and 2003 (Tables 1 and 2) consistently showed that increases in plant population density of maize in maize/cassava intercrop directly increased maize plant height at tasselling, plant height at harvest and plant lodging percentage, but reduced stalk diameter, average cob weight, dry matter yield and grain yield. Thus, in both years, plant population density at 80,000 plants/ha gave significantly $(P=0.05)$ tallest plants at tasselling and at harvest compared to plant population density of 20,000, 40,000 and the standard 53,333 plants/ha. Also, there were significantly highest maize lodging percentage (19.7 and 22.4\%) in 2002 and 2003 under plant population density of 80,000 plants/ha compared to plant population densities of $20,000,40,000$ and the standard 53,333 plants/ha. There were, however, significantly least values $(1.01$ and $1.05 \mathrm{~cm} ; 118.3$ and $115.7 \mathrm{~g} ; 2.08$ and $2.14 \mathrm{~g} / \mathrm{plant}$ ) recorded for plant stalk diameter, average cob weight and dry matter yield in 2002 and 2003 respectively under 80,000 plants/ha compared to plant population densities of 20,000, 40,000 and the standard 53,333 plants/ha. But, significantly least (2.03 and $2.11 \mathrm{t} / \mathrm{ha})$ were obtained from maize grain yield in 2002 and 2003 under 40,000 plant/ha. Similarly, significantly highest values (160.8 and $165.7 \mathrm{~g}$ ) were obtained from average cob weight in 2002 and 2003 under 20,000 plants/ha. However, this was not significantly different from 40,000 plants/ha plant population density. Inversely, significantly least values were obtained under 53,000 and 80,000 plants/ha. 
Table 1. Effects of varying maize plant population density in cassava/maize intercrop on maize growth and yield in 2002

\begin{tabular}{|c|c|c|c|c|c|c|c|}
\hline Treatments & $\begin{array}{l}\text { Plant height } \\
\text { at tasselling } \\
(\mathrm{cm})\end{array}$ & $\begin{array}{l}\text { Plant height } \\
\text { at harvesting } \\
(\mathrm{cm})\end{array}$ & $\begin{array}{l}\text { Plant stalk } \\
\text { diameter } \\
(\mathrm{cm})\end{array}$ & $\begin{array}{l}\text { Plant lodging } \\
\text { percentage } \\
(\%)\end{array}$ & $\begin{array}{l}\text { Average } \\
\text { cob weight } \\
\text { (g) }\end{array}$ & $\begin{array}{l}\text { Dry matter } \\
\text { yield } \\
\text { (g/plant) }\end{array}$ & $\begin{array}{l}\text { Maize grain } \\
\text { yield } \\
(\mathrm{t} / \mathrm{ha})\end{array}$ \\
\hline $\begin{array}{l}\text { Cassava/maize (at } 20,000 \\
\text { plants/ha of maize plants) }\end{array}$ & $198.5 \mathrm{c}$ & $228.3 \mathrm{c}$ & $1.21 \mathrm{a}$ & $8.64 d$ & $160.8 \mathrm{a}$ & $2.67 \mathrm{a}$ & $1.98 \mathrm{c}$ \\
\hline $\begin{array}{l}\text { Cassava/maize (at } 40,000 \\
\text { plants/ha of maize plants) }\end{array}$ & $209.1 \mathrm{~b}$ & $252.2 \mathrm{~b}$ & $1.10 \mathrm{~b}$ & $14.3 \mathrm{c}$ & $158.8 \mathrm{a}$ & $2.57 \mathrm{~b}$ & $3.28 \mathrm{a}$ \\
\hline $\begin{array}{l}\text { Cassava/maize (at } 53,333 \\
\text { plants/ha of maize plants) }\end{array}$ & $214.8 \mathrm{~b}$ & $257.3 b$ & $1.08 \mathrm{~b}$ & $16.8 \mathrm{~b}$ & $132.6 \mathrm{~b}$ & $2.30 \mathrm{c}$ & $2.76 \mathrm{~b}$ \\
\hline $\begin{array}{l}\text { Cassava/maize (at } 80,000 \\
\text { plants/ha of maize plants) }\end{array}$ & $228.9 a$ & $290.6 \mathrm{a}$ & $1.01 \mathrm{c}$ & $19.7 \mathrm{a}$ & $118.3 \mathrm{c}$ & $2.08 \mathrm{~d}$ & $2.39 b$ \\
\hline
\end{tabular}

Means with different letter(s) are statistically different by DMRT.

Table 2. Effects of varying maize plant population density in cassava/maize intercrop on maize growth and yield in 2003

\begin{tabular}{llllllll}
\hline & $\begin{array}{l}\text { Plant height } \\
\text { at tasselling } \\
\text { Treatments }\end{array}$ & $\begin{array}{l}\text { Plant height } \\
\text { at harvesting } \\
(\mathrm{cm})\end{array}$ & $\begin{array}{l}\text { Plant stalk } \\
\text { diameter } \\
(\mathrm{cm})\end{array}$ & $\begin{array}{l}\text { Plant lodging } \\
\text { percentage } \\
(\%)\end{array}$ & $\begin{array}{l}\text { Average } \\
\text { cob weight } \\
(\mathrm{g})\end{array}$ & $\begin{array}{l}\text { Dry matter } \\
\text { yield }\end{array}$ & $\begin{array}{l}\text { Maize } \\
\text { grain yield } \\
(\mathrm{g} / \mathrm{plant})\end{array}$ \\
$\begin{array}{l}\text { Cassava/ma) } \\
\text { plants/ha of maize plants) }\end{array}$ & $203.2 \mathrm{c}$ & $222.3 \mathrm{c}$ & $1.24 \mathrm{a}$ & $7.34 \mathrm{~d}$ & $165.7 \mathrm{a}$ & $2.85 \mathrm{a}$ & $2.11 \mathrm{c}$ \\
$\begin{array}{l}\text { Cassava/maize (at } 40,000 \\
\text { plants/ha of maize plants) }\end{array}$ & $217.1 \mathrm{~b}$ & $250.6 \mathrm{~b}$ & $1.17 \mathrm{~b}$ & $12.7 \mathrm{c}$ & $162.1 \mathrm{a}$ & $2.64 \mathrm{~b}$ & $3.55 \mathrm{a}$ \\
$\begin{array}{l}\text { Cassava/maize (at 53,333 } \\
\text { plants/ha of maize plants) }\end{array}$ & $214.8 \mathrm{~b}$ & $254.4 \mathrm{~b}$ & $1.15 \mathrm{~b}$ & $18.7 \mathrm{~b}$ & $134.3 \mathrm{~b}$ & $2.42 \mathrm{c}$ & $2.62 \mathrm{~b}$ \\
$\begin{array}{l}\text { Cassava/maize (at 80,000 } \\
\text { plants/ha of maize plants) }\end{array}$ & $230.4 \mathrm{a}$ & $290.4 \mathrm{a}$ & $1.05 \mathrm{c}$ & $22.4 \mathrm{a}$ & $115.7 \mathrm{c}$ & $2.14 \mathrm{~d}$ & $2.27 \mathrm{~b}$ \\
\hline
\end{tabular}

Means with different letter(s) are statistically different by DMRT.

Several workers have reported the effects of maize population density on agronomic characteristics of maize recorded the in this study. Duncan (1958) and Early et al. (1967) indicated that the effect is mainly due to competition for light, moisture and soil nutrients. In this study, it was observed that maize plant population density at 80,000 plants/ha exerted strong effect on maize height, stalk diameter and lodging percentage. Enyi (1973) and Hunt et al. (1977) explained the observed trend of plant height and internodes length with increasing plant population density to competition for light. In addition, the trend observed for stalk diameter and lodging percentage with increasing maize plant population density agrees with findings of Elliot and Miller, cited by Wahua et al. (1981). They indicated that the stem of peas like other plants elongated according to the degree of shading imposed on them. When this happened, high incidence of lodging at high density was due to the weak and with cobs placed higher in the stalks, a high degree of leverage is produced with tendency to induce lodging and stem breakage.

Grain yield per hectare obtained in this study increased with increased plant population density from 20,000 plants per hectare to 40,000 plants per hectare but significantly dropped with further increased in plant population density from 40,000 plants per hectare to 80,000 plants per hectare. Plant population density resulting in competition affects vegetative and reproductive growth. Maize reproductive response to plant population density has generally shown that individual plant yield decreases as plant per unit area increases (Duncan, 1958). Prior and Russell (1975) reported an increased kernel yield with plant population density up to 51,000 plants per hectare, followed by decreasing yield with further increases of population density up to 72,000 plants per hectare., i.e. a parabolic responses. This is suggesting that, the competition among the maize plant at high plant density for light resulted in the reduction in dry matter formation, and the plants produced smaller cobs. This has 
been confirmed by the results obtained from this study.

\subsection{Cassava}

Results obtained in 2002 and 2003 (Tables 3 and 4) showed that increased in plant population density of maize in cassava/maize intercropping system significantly affected the plant height at 2 and 4 months after planting (MAP) and fresh tuber yield of cassava. However, increased in plant population density of maize in cassava/maize intercrop did not significantly affect cassava plant height at 7 and 12 MAP. The highest values (43.8 and $40.2 \mathrm{~cm})$ and $(119.6$ and $110.4 \mathrm{~cm})$ were obtained for plant height at 2 and 4 MAP in 2002 and 2003 respectively under 20,000 plants/ha maize component which was not significantly different from 40,000 plants/ha maize component while the least values $(86.5$ and $81.2 \mathrm{~cm})$ were obtained in 2002 and 2003 under 80,000 plants/ha maize component. The highest values ( 25.9 and $25.3 \mathrm{t} / \mathrm{ha}$ ) cassava fresh tuber yield were obtained in 2002 and 2003 under 80,000 plants/ha maize component, although, this was not significantly different from that of 40,000 plants/ha maize component. The least values (17.6 and $18.2 \mathrm{t} / \mathrm{ha}$ ) were obtained in 2002 and 2003 under 80,000 plants/ha maize component.

Table 3. Effects of varying maize plant population density in cassava/maize intercrop on maize growth and yield in 2002

\begin{tabular}{|c|c|c|c|c|c|}
\hline Treatments & $\begin{array}{l}\text { Plant height at } 2 \\
\text { months after } \\
\text { planting (MAP) } \\
(\mathrm{cm})\end{array}$ & $\begin{array}{l}\text { Plant height at } 2 \\
\text { months after } \\
\text { planting (MAP) } \\
(\mathrm{cm})\end{array}$ & $\begin{array}{l}\text { Plant height at } 2 \\
\text { months after } \\
\text { planting (MAP) } \\
(\mathrm{cm})\end{array}$ & $\begin{array}{l}\text { Plant height at } 2 \\
\text { months after planting } \\
\text { (MAP) } \\
(\mathrm{cm})\end{array}$ & $\begin{array}{l}\text { Fresh tuber } \\
\text { yield } \\
(\mathrm{t} / \mathrm{ha})\end{array}$ \\
\hline $\begin{array}{l}\text { Cassava/maize (at } 20,000 \\
\text { plants/ha of maize plants) }\end{array}$ & $43.8 \mathrm{a}$ & $119.6 \mathrm{a}$ & $201.7 \mathrm{a}$ & $224.2 \mathrm{a}$ & $25.9 \mathrm{a}$ \\
\hline $\begin{array}{l}\text { Cassava/maize (at } 40,000 \\
\text { plants/ha of maize plants) }\end{array}$ & $41.3 \mathrm{a}$ & $114.5 \mathrm{a}$ & $196.7 \mathrm{a}$ & $219.3 \mathrm{a}$ & $24.4 \mathrm{a}$ \\
\hline $\begin{array}{l}\text { Cassava/maize (at } 53,333 \\
\text { plants/ha of maize plants) }\end{array}$ & $32.4 \mathrm{c}$ & $95.2 \mathrm{c}$ & $187.4 \mathrm{a}$ & $216.2 \mathrm{a}$ & $19.5 \mathrm{~b}$ \\
\hline $\begin{array}{l}\text { Cassava/maize (at } 80,000 \\
\text { plants/ha of maize plants) }\end{array}$ & $29.8 \mathrm{~d}$ & $86.5 \mathrm{~d}$ & $182.9 \mathrm{a}$ & $212.4 \mathrm{a}$ & $17.6 \mathrm{c}$ \\
\hline
\end{tabular}

Means with different letter(s) are statistically different by DMRT.

Table 4. Effects of varying maize plant population density in cassava/maize intercrop on maize growth and yield in 2003

\begin{tabular}{|c|c|c|c|c|c|}
\hline Treatments & $\begin{array}{l}\text { Plant height at } 2 \\
\text { months after } \\
\text { planting (MAP) } \\
(\mathrm{cm})\end{array}$ & $\begin{array}{l}\text { Plant height at } 2 \\
\text { months after } \\
\text { planting (MAP) } \\
(\mathrm{cm})\end{array}$ & $\begin{array}{l}\text { Plant height at } 2 \\
\text { months after } \\
\text { planting (MAP) } \\
(\mathrm{cm})\end{array}$ & $\begin{array}{l}\text { Plant height at } 2 \\
\text { months after } \\
\text { planting (MAP) } \\
(\mathrm{cm})\end{array}$ & $\begin{array}{l}\text { Fresh tuber yield } \\
(\mathrm{t} / \mathrm{ha})\end{array}$ \\
\hline $\begin{array}{l}\text { Cassava/maize (at } 20,000 \\
\text { plants/ha of maize plants) }\end{array}$ & $40.2 \mathrm{a}$ & $110.4 \mathrm{a}$ & $225.2 \mathrm{a}$ & $225.4 \mathrm{a}$ & $25.3 \mathrm{a}$ \\
\hline $\begin{array}{l}\text { Cassava/maize (at } 40,000 \\
\text { plants/ha of maize plants) }\end{array}$ & $38.6 \mathrm{a}$ & $105.4 \mathrm{a}$ & $218.7 \mathrm{a}$ & $220.1 \mathrm{a}$ & $23.5 \mathrm{a}$ \\
\hline $\begin{array}{l}\text { Cassava/maize (at } 53,333 \\
\text { plants/ha of maize plants) }\end{array}$ & $27.3 \mathrm{c}$ & $89.6 \mathrm{c}$ & $212.4 \mathrm{a}$ & $214.7 \mathrm{a}$ & $18.3 b$ \\
\hline $\begin{array}{l}\text { Cassava/maize (at } 80,000 \\
\text { plants/ha of maize plants) }\end{array}$ & $22.4 \mathrm{~d}$ & $81.2 \mathrm{~d}$ & $209.4 \mathrm{a}$ & $209.3 a$ & $18.2 \mathrm{~b}$ \\
\hline
\end{tabular}

Means with different letter(s) are statistically different by DMRT.

Intercropping of cassava with maize at different plant population density of maize component at early stage; $2^{\text {nd }}$ month through $4^{\text {th }}$ month after planting had effect on cassava growth due to above ground competition for light. In this study, cassava intercropped with maize on the same date was shaded on later dates during its association 
with maize. It could be deduced from this study that, by the second through the fourth month after planting, the cassava received less insolation for photosynthetic action. This is suggesting that, the competition of cassava with maize for light resulted in the reduction in dry matter (DM) formation, and the stems to attain greater height would assimilate less. Hunt et al. (1977) reported that under condition of low photosynthesis caused by low light levels, the supply of carbohydrate is low and the proportion of dry matter in the roots is decreased.

Contrary to the above situation with cassava, wherein the maize adversely shaded the cassava at the second through the fourth month after planting. It was observed that maize plant population density had no effect on height of cassava intercropped with maize at 7 and 12 MAP. This could be due to the fact that the cassava plants were well established after maize plants had been completely removed. Studies at International Institute of Tropical Agriculture (IITA, 1981) showed that there probably exists a shade threshold above which cassava plants cannot recover to perform well. In this study, the shade effect on cassava that was intercropped with maize on the same date of planting with no effect on height at 7 and 12 MAP suggesting that the threshold of shade at which the cassava could no longer recover from the shade effect had neither been reached nor exceeded.

\section{Conclusion}

This research has indicated that the intercropping as practiced by small scale farmers requires further improvement, especially in the area of plant population density of component crop(s). Therefore, it has been demonstrated that intercropping of cassava with maize at 40,000 plants/ha plant population density of maize compared to $20,000,80,000$ and the standard; 53,333 plants/ha would bring about the highest total productivity (yields of maize and cassava) per unit land area. This is capable of ensuring better income and sustained productivity among the small-scale, resource-poor farmers.

\section{References}

Adetiloye, P. O. (1985). Mathematical models for formulating intercrop population for intercropping systems design. Ecol. Modeling, 15, 81-93. http://dx.doi.org/10.1016/0304-3800(85)90026-2

Agboola, A. A., \& Fayemi, A. A. (1971). Preliminary trial on the intercropping of maize with different tropical legumes. J. Agric. Sci., 77, 219-255. http://dx.doi.org/10.1017/S0021859600024345

Baker, E. F. I. (1974). Research on mixed cropping with cereals in Nigeria farming system for improvement (pp. 207-301). Proceedings for international workshop on farming systems ICRISAT, Hyerbad.

Duncan, W. G. (1958). The relationship between corn population and yield. Agron. J., 50, 82-84. http://dx.doi.org/10.2134/agronj1958.00021962005000020008x

Early, E. B., Melbrath, W. D., Seif, R. D., \& Hageman, R. W. (1967). Effect of shade applied at different stages of plant development on corn production. Crop Sci., 7, 151-156. http://dx.doi.org/10.2135/cropsci1967.0011183X000700020018x

Enyi, B. A. C. (1973). Growth rate of three cassava varieties under varying population densities. J. Agric., 81, 15-28. http://dx.doi.org/10.1017/S0021859600058251

Ezumah, H. C., \& Okigbo, B. N. (1980). Cassava planting system in Africa. In E. J. Weder, J. C. Toro, \& M. Graham (Eds.), Cassava cultural practices (pp. 44-47). Ottawa: IDRC.

Fagbamiye, A. I. (1977). Investigation of traditional mixed cropping systems in the tropics (p. 365). PhD thesis in the Department of Agronomy, University of Ibadan, Nigeria.

Gomez, A. A., \& Gomez, K. A. (1983). Multiple cropping in the humid tropic of Asia (p. 289). Ottawa. Ontario: IDRC.

Harper, J. L. (1977). Population biology of plants. London Academic Press.

Hunt, I. A., Wholey, D. W., \& Cock, J. H. (1977). Growth physiology of cassava (Manihot esculenta crantz). Field Crop Abstract, 30(2), 77-89.

Ikeorgu, J. E. G. (2002). Performance of yam minituber/maize intercrop in the humid tropics of Southeast Nigeria. Niger. Agric. J., 33, 83-87.

Ikeorgu, J. E. G., Wuhua, T. A. T., \& Ezumah, H. C. (1984). In E. R. Terry, E. R. Doku, O. B. Arene, \& N. M. Mahungu (Eds.), Crop productivity in complex mixtures: 1. Melon and okra in cassava-maize intercrops (pp. 63-66). Proceedings of second Triennial Symposium of ISTRC-Africa Branch held in Douala. Cameroon, 14-19 August 1983. Ottawa, Canada: IDRC.

International Institute of Tropical Agriculture. (1980). Annual Report: 10-15. IITA Ibadan Nigeria. 
International Institute of Tropical Agriculture. (1981). Annual Report: 10-15. IITA Ibadan Nigeria.

Jerome, A. T., Lyonga, S. N., Agboola, A. A., \& Hahn, S. K. (1988). Performance of cassava-maize intercrop in Cameroon. Cassava-based cropping systems research II (pp. 42-45). Contributions from the second annual meeting of the second annual meeting of the collaborative group in cassava-based cropping systems research, 7-10 November 1988. Ibadan, Nigeria: IITA.

Numfor, F. A. (1987). Traditional post-harvest technologies of root and tuber crops in Cameroon. Agric. Survey, 78.

Oyedokun, J. B., Akinlosotu, Omidiji, M. O., \& Ezumah, H. C. (1989). Introduction of cassava through maize in a humid environment. Cassava-based cropping systems research II. 7-10 November 1988. Ibadan. Nigeria: IITA.

Prior, C. L., \& Russell, W. A. (1975). Yield performance on non-prolific and prolific maize hybrids at six plant densities. Crop Sci., 15, 482-486. http://dx.doi.org/10.2135/cropsci1975.0011183X001500040010x

Smyth, A. J., \& Montgomery. (1962). Soils and land use in Central western Nigeria (p. 265). The government of western Nigeria, Ibadan.

Snaydon, R. W., \& Satorre, E. H. (1989). Bivariate diagrams for plant competition data: Modification and interpretation. Journal of Applied Ecology, 26, 1043-1057. http://dx.doi.org/10.2307/2403711

Troyer, A. F., \& Rosenbrook, R. W. (1983). Utility of higher plant density for corn performance testing. Crop Science, 23, 863-867. http://dx.doi.org/10.2135/cropsci1983.0011183X002300050011x

Vandermeer, J. (1989). The ecology of intercropping. Cambridge University Press. http://dx.doi.org/10.1017/CBO9780511623523

Wahua, T. A. T., Babalola, O., \& Aken'ova, M. E. (1981). Intercropping morphologically different types of maize with cowpea: LER and growth attributes of associated cowpea. Expl. Agric., 17, 407-413. http://dx.doi.org/10.1017/S001447970001187X

\section{Copyrights}

Copyright for this article is retained by the author(s), with first publication rights granted to the journal.

This is an open-access article distributed under the terms and conditions of the Creative Commons Attribution license (http://creativecommons.org/licenses/by/3.0/). 